\title{
The Pyruvate Dehydrogenase Complex of Pseudomonas aeruginosa PAO. Purification, Properties and Characterization of Mutants
}

\author{
By KANDIAH JEYASEELAN,1 JOHN R. GUEST ${ }^{1 *}$ AND JAAP VISSER \\ 1 Department of Microbiology, University of Sheffield, Sheffield S10 2TN \\ 2 Department of Genetics, Agricultural University, Wageningen, The Netherlands
}

(Received 12 May 1980)

\begin{abstract}
The pyruvate dehydrogenase complex of Pseudomonas aeruginosa PAO was purified by affinity chromatography on ethanol-Sepharose $2 \mathrm{~B}$ followed by sucrose density gradient centrifugation. The overall purification was 130 -fold based on enzyme activity. The purified complex contained three major and one minor polypeptide components when analysed by sodium dodecyl sulphate-polyacrylamide gel electrophoresis. These were identified by heat treatment, limited proteolysis and peptide mapping as pyruvate dehydrogenase $\left(\mathrm{E} 1 ; \mathrm{M}_{\mathrm{r}}\right.$ 92500), acetyltransferases (E2; major component, $M_{r} 76000$, and minor component, $M_{r}$ $77800)$ and lipoamide dehydrogenase $\left(E 3 ; M_{r} 58000\right)$. The purified complex had a sedimentation coefficient of $48 \mathrm{~S}$ and the specific activity for the overall reaction of the complex was $6.5 \mu$ mol substrate transformed (mg protein) $)^{-1} \mathrm{~min}^{-1}$ at the optimum $\mathrm{pH}(7.8)$ and $25^{\circ} \mathrm{C}$.

The lesions in four ace mutants lacking overall pyruvate dehydrogenase complex activity were identified after partial purification of the corresponding cell-free extracts. Three strains, designated ace $A$ mutants, lacked pyruvate dehydrogenase activity (E1 component) and one strain, an $a c e B$ mutant, lacked the activity of the acetyltransferase (E2 component).
\end{abstract}

\section{INTRODUCTION}

The pyruvate dehydrogenase complex catalyses the oxidative decarboxylation of pyruvate with the formation of acetyl-CoA, carbon dioxide and NADH. This multienzyme complex has been isolated from a number of sources (Reed, 1974; Bresters et al., 1975; Guest, 1978; Henderson et al., 1979). The bacterial complex consists of multiple copies of three enzymic components: pyruvate dehydrogenase (EC 1.2.4.1), dihydrolipoamide acetyltransferase (EC 2.3.1.12) and lipoamide dehydrogenase (EC 1.6.4.3).

Amongst the prokaryotes, three types of structural organization have been detected. In Escherichia coli the complex contains three different types of polypeptide chain: those specifying the pyruvate dehydrogenase $\left(E 1 ; M_{r} 96000\right.$ to 100000$)$, the acetyltransferase $\left(E 2 ; M_{r} 65000\right.$ to 89000$)$ and the lipoamide dehydrogenase (E3; $M_{r} 56500$ ) components (Reed, 1974; Vogel, 1977; Gebhardt et al., 1978). The complex is assembled around a structural core comprising 24 E2 chains (Reed, 1974; Danson et al., 1979). The polypeptide chain stoicheiometry (E1:E2:E3) of the complex is not definitely known and ratios of approximately 2:2:1 (Reed, 1974; Fuller et al., 1979; Angelides et al., 1979) and 1 to 2:1:1 (Vogel et al., 1972; Danson et al., 1979) have been proposed. Recent estimates of the sedimentation coefficient and molecular weight are 60.2S and 6.1 $\times 10^{6}$ (Danson et al., 1979).

The pyruvate dehydrogenase complex of Azotobacter vinelandii is much smaller (19S; $\mathrm{M}_{\mathrm{r}} 1 \times 10^{6}$ ) and contains four polypeptide chains (Bresters et al., 1975). Two acetyltransferase isoenzymes $\left(M_{r} 82000\right.$ and 59000$)$ have been identified in addition to the pyruvate dehydrogenase $\left(M_{r} 89000\right)$ and lipoamide dehydrogenase $\left(M_{r} 56000\right)$ components. This complex can be transformed into an active three-component complex by removal of the lower molecular weight acetyltransferase (De Abreu et al., 1977). 
Substantial differences in the structures of the pyruvate dehydrogenase complexes of Bacillus stearothermophilus and other Bacillus species exist (Henderson et al., 1979; J. Visser, unpublished observations; R. N. Perham, personal communication). The complexes of these Gram-positive bacteria resemble their mammalian counterparts with respect to their higher molecular weight $\left(9.6 \times 10^{6}\right)$, sizes of components and, particularly, the existence of two essential subunits for the pyruvate dehydrogenase component (Henderson et al., 1979). The subunit molecular weights are: pyruvate dehydrogenase components $\left(M_{r} 42000\right.$ and 36000), acetyltransferase $\left(M_{r} 57000\right)$ and lipoamide dehydrogenase $\left(M_{r} 54000\right)$.

Little is known about the pyruvate dehydrogenase complex of Pseudomonas aeruginosa PAO although four ace mutants lacking this activity have been isolated and their lesions located on the $P$. aeruginosa PAO linkage map (Jeyaseelan \& Guest, 1980). This paper describes the purification and some properties of the pyruvate dehydrogenase complex of $P$. aeruginosa PAO. In addition, the lesions of the ace mutants were identified after partial purification of the corresponding complexes.

\section{METHODS}

Organisms. Pseudomonas aeruginosa strain PAO1 was obtained from Professor B. W. Holloway. The four ace mutants (PAO2851 to 4) lacking overall pyruvate dehydrogenase complex activity have been described previously (Jeyaseelan \& Guest, 1980). Stock cultures of organisms grown for $16 \mathrm{~h}$ on slopes of nutrient agar were maintained at $-20^{\circ} \mathrm{C}$ by rapid freezing in nutrient yeast broth (NYB) medium and revived in the same medium (Stanisich \& Holloway, 1972). The wild-type strain of $E$. coli $(\mathrm{H})$ and other strains used in the immunological studies have been described previously (Langley \& Guest, 1977).

Growth of organisms and preparation of cell-free extracts. Batch cultures (6l) of $P$. aeruginosa PAO1 were grown at $37^{\circ} \mathrm{C}$ in the minimal medium of Jeyaseelan \& Guest (1980) with D-glucose (80 mM) as substrate in a Microferm fermenter (New Brunswick Scientific Co., New Brunswick, N.J., U.S.A.). Cultures of the ace mutants were grown in the same medium supplemented with potassium acetate $(4 \mathrm{~mm})$. The cultures were grown from a $15 \mathrm{ml}$ inoculum of organisms grown overnight in NYB; they were stirred at $200 \mathrm{rev}$. $\mathrm{min}^{-1}$ and aerated at 0.21 air $\mathrm{min}^{-1}$. Cultures were harvested in late-exponential phase (after $16 \mathrm{~h}$ ) at $15000 \mathrm{rev}$. $\min ^{-1}$ and $4{ }^{\circ} \mathrm{C}$ using the continuous action rotor of an HS18 centrifuge (M.S.E.). The bacterial paste $(20 \mathrm{~g}$ wet wt) was washed in $500 \mathrm{ml}$ potassium phosphate buffer $(10 \mathrm{mM} ; \mathrm{pH} 7.0)$ and resuspended in extraction buffer $(120 \mathrm{ml})$. The extraction buffer contained potassium phosphate buffer $(10 \mathrm{~mm} ; \mathrm{pH} 7 \cdot 0)$, EDTA ( $2 \mathrm{~mm})$, $\mathrm{MgCl}_{2}(3 \mathrm{mM})$,'phenylmethylsulphonyl fluoride (PMSF, $\left.50 \mu \mathrm{M}\right)$, 2-mercaptoethanol (5 mM), deoxyribonuclease I $\left(5 \mu \mathrm{g} \mathrm{ml}^{-1}\right)$, ribonuclease $\left(10 \mu \mathrm{g} \mathrm{ml}^{-1}\right)$ and thiamin pyrophosphate (TPP, $\left.100 \mu \mathrm{M}\right)$. The bacteria were disrupted with an ultrasonic disintegrator $(150 \mathrm{~W}$; M.S.E.) as $40 \mathrm{ml}$ portions for two periods of $2 \mathrm{~min}$ with an interval for cooling. The extract was centrifuged at $25000 \mathrm{~g}$ for $15 \mathrm{~min}$ at $0{ }^{\circ} \mathrm{C}$ and the supernatant fluid was dialysed at $4{ }^{\circ} \mathrm{C}$ against potassium phosphate buffer $(10 \mathrm{~mm}$; pH 7.0) containing all components of the extraction buffer except the nucleases and TPP.

Enzymology. The pyruvate dehydrogenase complex activity was measured spectrophotometrically at $340 \mathrm{~nm}$ and $25^{\circ} \mathrm{C}$ in $1 \mathrm{ml}$ cuvettes containing Tris/ $\mathrm{HCl}$ buffer $(100 \mathrm{~mm} ; \mathrm{pH} 7 \cdot 8)$, pyruvate $(5 \mathrm{~mm}), \mathrm{MgCl}_{2}$ $(2 \mathrm{mM})$, dithiothreitol $(2.5 \mathrm{mM})$, TPP $(0.4 \mathrm{mM}), \mathrm{CoA}(130 \mu \mathrm{M})$ and $\mathrm{NAD}^{+}(0.6 \mathrm{mM})$. The 2-oxoglutarate dehydrogenase complex activity was measured under similar conditions with 2-oxoglutarate as the substrate.

The pyruvate dehydrogenase (E1; EC 1 2.4.1) component was assayed spectrophotometrically at $420 \mathrm{~nm}$ and pH 6.3 with ferricyanide as the electron acceptor (Hager \& Kornberg, 1961).

The dihydrolipoamide acetyitransferase (E2; EC 2.3.1.12) component was determined as described previously (Jeyaseelan \& Guest, 1980).

The lipoanide dehydrogenase (E3; EC 1.6.4.3) component was measured at $25^{\circ} \mathrm{C}$ in $1 \mathrm{ml}$ cuvettes containing potassium phosphate buffer $(100 \mathrm{~mm} ; \mathrm{pH} 7 \cdot 8)$, bovine serum albumin $(0.01 \%, \mathrm{w} / \mathrm{v})$, EDTA $(1 \mathrm{~mm})$, reduced lipoamide $(0.6 \mathrm{~mm})$ and $\mathrm{NAD}^{+}(0.36 \mathrm{~mm})$.

For assays involving crude extracts, $\mathrm{NAD}^{+}$was replaced by 3 -acetylpyridine-adenine dinucleotide $\left(\mathrm{APAD}^{+}\right)$ (to prevent interference from NADH oxidase) and absorbances were recorded at $366 \mathrm{~nm}$. However, this precaution was not necessary because the observed rates were the same with the two coenzymes. Enzyme specific activities are quoted in enzyme units (mg protein) ${ }^{-1}$, where one unit is the amount of enzyme transforming $1 \mu \mathrm{mol}$ substrate min $^{-1}$. Protein concentrations were determined by the Lowry method with bovine serum albumin as the standard and all enzyme specific activities are based on this method even though absorbance at $280 \mathrm{~nm}$ was used to monitor the purification.

Affinity chromatography. The ethanol-Sepharose 2B matrix of Visser et al. (1978) was used as the first 
step in the purification of the pyruvate dehydrogenase complex. The crude extract was loaded on a column $(2.5 \times 20 \mathrm{~cm})$ equilibrated with potassium phosphate buffer $(10 \mathrm{~mm} ; \mathrm{pH} 7.0)$ containing EDTA, PMSF, $\mathrm{MgCl}_{2}$ and 2-mercaptoethanol at the concentrations described above (for extraction buffer). The column was eluted with the same buffer and fractions $(10 \mathrm{ml})$ were collected at a flow rate of $30 \mathrm{ml} \mathrm{h}^{-1}$. When all the unbound proteins had been removed the enzyme was eluted at the same flow rate with the same buffer but an increasing potassium phosphate concentration (10 to $80 \mathrm{~mm}$, linear gradient). Fractions containing pyruvate dehydrogenase complex were pooled and the activity was concentrated by ultracentrifugation.

Ultracentrifugation. Pooled fractions from the ethanol-Sepharose column were centrifuged at $140000 \mathrm{~g}$ for $4.5 \mathrm{~h}$ at $4{ }^{\circ} \mathrm{C}\left(40000 \mathrm{rev} . \mathrm{min}^{-1}\right.$ in the $8 \times 35 \mathrm{ml}$ fixed angle rotor of the M.S.E. Prepspin 50$)$. The sediment was carefully dissolved in sodium phosphate buffer ( $30 \mathrm{~mm}$; $\mathrm{pH} 7.0)$ containing EDTA (2 mM). Insoluble material was removed by low-speed centrifuging $(2500 \mathrm{~g}$ for $10 \mathrm{~min}$ ).

Sucrose gradients. Concentrated samples $(1 \mathrm{ml})$ were applied to linear sucrose gradients $(5$ to $15 \%, \mathrm{w} / \mathrm{w})$ containing sodium phosphate buffer (30 mM; pH 7.0) and EDTA ( $2 \mathrm{~mm})$. They were centrifuged at $140000 \mathrm{~g}$ (39000 rev. $\mathrm{min}^{-1}$ ) for $3 \mathrm{~h}$ at $4^{\circ} \mathrm{C}$ in a Beckman L2-65B preparative ultracentrifuge using a $6 \times 14 \mathrm{ml}(\mathrm{SW} 40)$ swing-out rotor. Fractions $(1 \mathrm{ml})$ were collected and assayed for pyruvate dehydrogenase complex and lipoamide dehydrogenase activities. The sucrose concentration was determined with an Abbé refractometer. Samples were dialysed against sodium phosphate buffer $(30 \mathrm{~mm} ; \mathrm{pH} 7.0)$ with EDTA (2 mM) to remove sucrose.

Sodium dodecyl sulphate-polyacrylamide gel electrophoresis. Electrophoresis in $10 \%(\mathrm{w} / \mathrm{v})$ polyacrylamide gels containing $0 \cdot 1 \%(\mathrm{w} / \mathrm{v})$ sodium dodecyl sulphate was performed in the vertical slab gel apparatus described by Studier (1973) using a discontinuous sodium dodecyl sulphate buffer system (Laemmli, 1970). Gels were stained with Kenacid blue R. The molecular weights of the protein subunits were estimated by comparison with the following marker proteins: $\beta$-galactosidase (116000), phosphorylase $\mathrm{b}(94000)$, conalbumin, type I (78000), bovine serum albumin (68000), catalase (60000), ovalbumin (43000), carbonic anhydrase (29000) and trypsin inhibitor protein (21500). Samples of $E$. coli pyruvate dehydrogenase complex were also included as reference proteins and for comparison with the $\boldsymbol{P}$. aeruginosa complex. The gels were scanned using a Unicam SP1809 scanning densitometer at $550 \mathrm{~nm}$.

Sedimentation analysis. Sedimentation measurements were performed in a Beckman Spinco Model E ultracentrifuge at a rotor speed of $55740 \mathrm{rev} \cdot \mathrm{min}^{-1}$ at $20^{\circ} \mathrm{C}$. Migration of the boundary was followed using Schlieren optics and the boundaries were measured at $4 \mathrm{~min}$ intervals. Sedimentation was in sodium phosphate buffer $(30 \mathrm{~mm} ; \mathrm{pH} 7.0)$ containing EDTA $(2 \mathrm{mM})$ and the protein concentration was $0.9 \mathrm{mg} \mathrm{ml}^{-1}$.

Peptide mapping. Peptide mapping by limited proteolysis in sodium dodecyl sulphate and analysis by polyacrylamide gel electrophoresis was done according to Cleveland $e t$ al. (1977). Bands $(1 \times 5 \mathrm{~mm})$ from stained gels were treated with 2 to $5 \mathrm{ng}$ Staphylococcus aureus V8 protease for $15 \mathrm{~min}$ in the stacking gel above the second separating gel ( $15 \%$ acrylamide).

Immunology. Antisera raised against the pyruvate dehydrogenase complex and the pyruvate dehydrogenase and lipoamide dehydrogenase components of $E$. coli were used in Ouchterlony double diffusion with crude extracts of $P$. aeruginosa as described previously (Guest \& Creaghan, 1974).

Quantitative titrations of enzymic activities with antisera were carried out by incubating samples of crude extract, having complex activities of $2 \mu \mathrm{mol} \mathrm{h}^{-1}$, at room temperature for $30 \mathrm{~min}$ with different amounts of antisera (final volume $250 \mu \mathrm{l}$ ). The mixtures were then centrifuged for $20 \mathrm{~min}$ at $10000 \mathrm{~g}\left(4^{\circ} \mathrm{C}\right)$ and the supernatants were tested for residual enzyme activity (Langley \& Guest, 1974).

The antiserum raised against the $E$. coli pyruvate dehydrogenase component exhibited minor reactions with lipoamide dehydrogenase and two non-specific bacterial components. It was made monospecific by mixing the antiserum $(3 \mathrm{ml})$ with protein $(0.03 \mathrm{mg})$ derived from cell-free extracts of $E$. coli deletion mutants

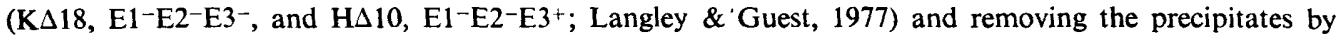
sedimentation at $10000 \mathrm{~g}$.

Materials. Dihydrolipoamide was prepared by reducing $300 \mathrm{mg}$ lipoamide (Sigma) in methanol plus water $(6 \mathrm{ml}$ plus $1.5 \mathrm{ml})$ with sodium borohydride $\left(30 \mathrm{mg}\right.$ in $1.5 \mathrm{ml}$ water) at $0{ }^{\circ} \mathrm{C}$. The product was extracted with chloroform, dried and recrystallized from benzene/n-hexane (2.5:1, by vol.). Other substrates and coenzymes were purchased from Boehringer or Sigma. Pyruvate dehydrogenase complex of $E$. coli strain K1-1LR8-13 was prepared according to Visser et al. (1978). The sources of other chemicals, enzymes and proteins were: $\mathrm{BDH}$ - deoxyribonuclease 1 and ribonuclease; Boehringer $-\beta$-galactosidase, phosphorylase $\mathrm{b}$ and trypsin inhibitor (soybean); Koch-Light - catalase; Sigma - conalbumin, bovine serum albumin, ovalbumin, carbonic anhydrase and phenylmethylsulphonyl fluoride (PMSF). 


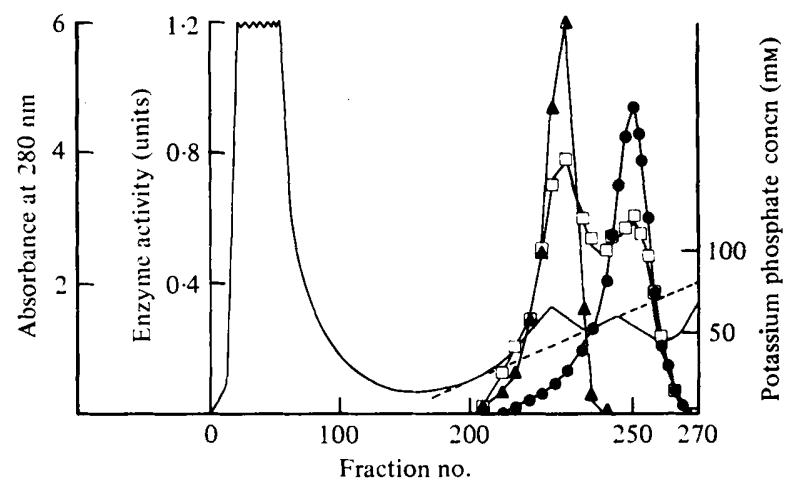

Fig. 1. Affinity chromatography of the 2-oxoacid dehydrogenase complexes of $P$. aeruginosa PAO1 on ethanol-Sepharose 2B. Crude extract was prepared from $20 \mathrm{~g}$ wet wt bacteria and chromatographed according to the procedures described in Methods. Fractions of $10 \mathrm{ml}$ were collected and assayed for pyruvate dehydrogenase complex activity (O), 2-oxoglutarate dehydrogenase complex activity $(\boldsymbol{\Delta})$ and lipoamide dehydrogenase activity $(\square)$. The potassium phosphate gradient $(---)$ and absorbance at $280 \mathrm{~nm}(-)$ are indicated.

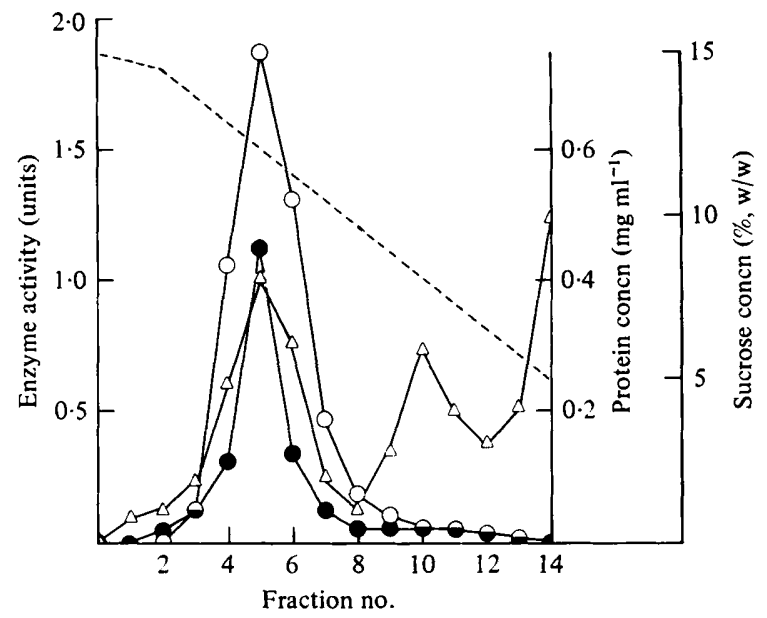

Fig. 2. Purification of pyruvate dehydrogenase complex of $P$. aeruginosa PAO1 by sucrose density gradient centrifugation. Samples $(1 \mathrm{ml})$ concentrated after ethanol-Sepharose $2 \mathrm{~B}$ chromatography were layered on linear sucrose gradients $(5$ to $15 \%, w / w)$ and centrifuged at $140000 \mathrm{~g}$ for $3 \mathrm{~h}$ at $4{ }^{\circ} \mathrm{C}$. Fourteen fractions of $1 \mathrm{ml}$ were collected and assayed for pyruvate dehydrogenase complex activity $(\bigcirc)$ and lipoamide dehydrogenase activity $(\bigcirc)$. The sucrose gradient $(---)$ and protein concentration based on the Lowry method $(\Delta)$ are indicated.

\section{RESULTS}

The pyruvate dehydrogenase complex of $P$. aeruginosa $\mathrm{PAO}$

Purification. The elution profile of the pyruvate and 2-oxoglutarate dehydrogenase complex activities and lipoamide dehydrogenase on ethanol-Sepharose 2B is shown in Fig. 1. The 2-oxoglutarate dehydrogenase complex was eluted first, at low ionic strength, followed by the pyruvate dehydrogenase complex at a higher ionic strength. About $80 \%$ of the pyruvate dehydrogenase complex applied was recovered, free from contamination with 2-oxoglutarate dehydrogenase complex, with an overall purification of 12-fold. Lipoamide dehydrogenase activity was associated with both complexes. The pyruvate dehydrogenase complex was concentrated by sedimenting at $140000 \mathrm{~g}$ for $4.5 \mathrm{~h}$ and several non-sedimentable contaminants were also eliminated. Further purification was achieved by centrifuging on 


\section{Table 1. Purification of the pyruvate dehydrogenase complex of P. aeruginosa PAO1}

The results of a typical purification starting with $20 \mathrm{~g}$ wet wt bacteria are shown. Enzymes were assayed as described in Methods using APAD ${ }^{+}$with crude extracts, but $\mathrm{NAD}^{+}$for other fractions. Abbreviations: pdhc, pyruvate dehydrogenase complex; E1, pyruvate dehydrogenase; E2, dihydrolipoamide acetyltransferase; E3, lipoamide dehydrogenase.

\begin{tabular}{|c|c|c|c|c|c|c|}
\hline $\begin{array}{l}\text { Purification } \\
\text { step }\end{array}$ & $\begin{array}{l}\text { Total } \\
\text { volume } \\
(\mathrm{ml})\end{array}$ & $\begin{array}{l}\text { Total } \\
\text { protein } \\
(\mathrm{mg})\end{array}$ & $\begin{array}{l}\text { Activity } \\
\text { assayed }\end{array}$ & $\begin{array}{l}\text { Total } \\
\text { activity } \\
\text { (units) }\end{array}$ & $\begin{array}{l}\text { Specific activity } \\
\text { [units (mg } \\
\left.\text { protein })^{-1}\right]\end{array}$ & $\begin{array}{l}\text { Yield } \\
(\%)\end{array}$ \\
\hline Crude extract & 120 & 1620 & $\begin{array}{l}\text { pdhc } \\
\text { E1 } \\
\text { E2 } \\
\text { E3 }\end{array}$ & $\begin{array}{l}81 \cdot 6 \\
32 \cdot 4 \\
40 \cdot 8 \\
56 \cdot 4\end{array}$ & $\begin{array}{l}0.05 \\
0.02 \\
0.025 \\
0.035\end{array}$ & $\begin{array}{l}100 \\
100 \\
100 \\
100\end{array}$ \\
\hline $\begin{array}{l}\text { Ethanol- } \\
\text { Sepharose }\end{array}$ & 105 & 101 & $\begin{array}{l}\text { pdhc } \\
\text { E1 } \\
\text { E2 } \\
\text { E3 }\end{array}$ & $\begin{array}{l}60 \cdot 9 \\
23 \cdot 1 \\
29 \cdot 4 \\
26 \cdot 3\end{array}$ & $\begin{array}{l}0 \cdot 61 \\
0 \cdot 23 \\
0 \cdot 29 \\
0 \cdot 26\end{array}$ & $\begin{array}{l}74 \cdot 6 \\
71 \cdot 3 \\
72 \cdot 1 \\
46 \cdot 6\end{array}$ \\
\hline Sedimentation & 6 & 27 & $\begin{array}{l}\text { pdhc } \\
\text { E1 } \\
\text { E2 } \\
\text { E3 }\end{array}$ & $\begin{array}{l}56 \cdot 7 \\
21 \cdot 0 \\
27 \cdot 6 \\
24 \cdot 9\end{array}$ & $\begin{array}{l}2 \cdot 10 \\
0 \cdot 78 \\
1 \cdot 02 \\
0.92\end{array}$ & $\begin{array}{l}69 \cdot 5 \\
64 \cdot 8 \\
67 \cdot 6 \\
44 \cdot 2\end{array}$ \\
\hline Sucrose gradient & 18 & $7 \cdot 2$ & $\begin{array}{l}\text { pdhc } \\
\text { E1 } \\
\text { E2 } \\
\text { E3 }\end{array}$ & $\begin{array}{l}46 \cdot 8 \\
17 \cdot 3 \\
24 \cdot 3 \\
21 \cdot 6\end{array}$ & $\begin{array}{l}6 \cdot 5 \\
2 \cdot 4 \\
3 \cdot 4 \\
3 \cdot 0\end{array}$ & $\begin{array}{l}57 \cdot 4 \\
53 \cdot 1 \\
59 \cdot 6 \\
38 \cdot 3\end{array}$ \\
\hline
\end{tabular}

sucrose density gradients (see Methods) and an activity profile for the complex and lipoamide dehydrogenase is shown in Fig. 2. The specific activity of pooled fractions 4 to 6 was 6.5 units (mg protein) $)^{-1}$, corresponding to an overall purification of 130 -fold and a $57 \%$ recovery of activity. Details of a typical purification are summarized in Table 1 . There was no appreciable loss of individual component activities (Table 1) during the purification except for lipoamide dehydrogenase, which was distributed between the two complexes at the first step. Attempts to purify the ethanol-Sepharose fractions by calcium phosphate gel chromatography, gel filtration on Sepharose 6B (Henderson et al., 1979) or affinity chromatography on propanolSepharose 2B and ethylene glycol-Sepharose 2B (J. Visser, unpublished observations), instead of by the final centrifugation procedure, were unsuccessful.

The purified complex was stable in sodium phosphate buffer $(30 \mathrm{~mm} ; \mathrm{pH} 7 \cdot 0)$ containing EDTA ( $2 \mathrm{~mm}$ ) for up to 4 weeks at $-20^{\circ} \mathrm{C}$. Under standard assay conditions the optimum $\mathrm{pH}$ for overall complex activity was 7.8 in $\mathrm{Tris} / \mathrm{HCl}$ and potassium phosphate buffers. The activity fell steadily on either side of the maximum and was $50 \%$ of the optimal rate at $\mathrm{pH} 6 \cdot 8$ and $\mathrm{pH} 8 \cdot 8$.

On analytical ultracentrifugation of the purified complex a single component having a sedimentation coefficient $\left(s_{20, w}\right)$ of $48 \mathrm{~S}$ was detected. After storage at $-20^{\circ} \mathrm{C}$ for 4 weeks the complex degraded into three components of 47,13 and $12 \cdot 5 \mathrm{~S}$, without loss of activity.

Molecular weights and identification of the subunits. Sodium dodecyl sulphate-polyacrylamide gel electrophoretic analysis indicated that the purified complex contained four polypeptides, although one was generally a minor component (Fig. 3). The molecular weights $\left(\mathrm{M}_{\mathrm{r}}\right)$ of these components, as estimated from their rate of migration relative to reference proteins, were: $92500,77800,76000$ and 58000 . Under the same conditions the molecular weights of the components of the pyruvate dehydrogenase complex of $E$. coli were estimated to be 96500 (E1), 83000 (E2) and 56000 (E3).

Attempts to identify the polypeptides by dissociating the complex were unsuccessful because it was unaffected by procedures such as treatment with alkali $(\mathrm{pH} \mathrm{10})$ or potassium iodide $(2 \mathrm{M})$, which normally dissociate the complexes of other bacteria (Bates et al., 1977; Henderson et al., 1979). However, evidence for the identities of the polypeptides was obtained 

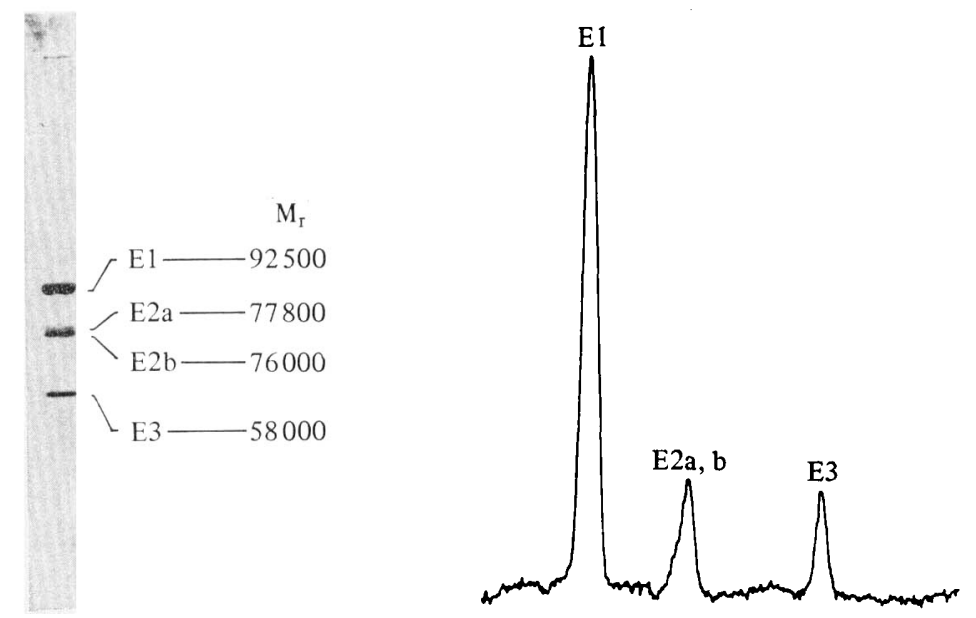

Fig. 3. Sodium dodecyl sulphate-polyacrylamide gel electrophoresis of pyruvate dehydrogenase complex of $P$. aeruginosa PAO1. A sample of the purified complex ( $25 \mu \mathrm{g}$ protein) was analysed and the stained gel was scanned at $550 \mathrm{~nm}$ using a Unicam SP1809 scanning densitometer. The molecular weights of the polypeptide chains were estimated by comparison with standard marker proteins and the pyruvate dehydrogenase complex of $E$. coli (see Methods).

from their differential stabilities to heat and proteolysis with trypsin. Heating the partially purified complex (ethanol-Sepharose fraction) in buffer plus ammonium sulphate $(5 \%$, $\mathrm{w} / \mathrm{v}$ ) for $5 \mathrm{~min}$ at $70^{\circ} \mathrm{C}$ followed by centrifuging $\left(25000 \mathrm{~g}\right.$ for $15 \mathrm{~min}$ at $4{ }^{\circ} \mathrm{C}$ ) and dialysis of the supernatant fluid, totally inactivated the overall complex and its pyruvate dehydrogenase component (E1) and also eliminated the 92500 polypeptide from the gel profile (Fig. 3). The other enzyme activities and polypeptide components were unaffected. A second similar heat treatment inactivated the acetyltransferase component (E2) and removed all of the 77800 and most of the 76000 polypeptides: most of the lipoamide dehydrogenase activity (E3 component) and the 58000 polypeptide were retained. The identities of the E2 and $\mathrm{E} 3$ components were confirmed by limited proteolysis of the purified complex with trypsin [0.2 mg complex plus $5 \mu \mathrm{g}$ trypsin in $0.5 \mathrm{ml}$ sodium phosphate buffer $(30 \mathrm{~mm} ; \mathrm{pH} 7.0)$ for 1 to $20 \mathrm{~min}$ ]. Within $5 \mathrm{~min}$ the acetyltransferase activity was lost and the 77800 and 76000 polypeptides were replaced by polypeptides of lower molecular weight. The 92500 polypeptide disappeared less rapidly but the lipoamide dehydrogenase activity (E3 component) and the 58000 polypeptide were completely unaffected after treating for up to $20 \mathrm{~min}$. Thus, the largest (92500) and smallest (58000) polypeptides correspond to the pyruvate dehydrogenase (E1) and lipoamide dehydrogenase (E3) components, respectively, and one, or both, of the other polypeptides $(77800, \mathrm{E} 2 \mathrm{a} ; 76000, \mathrm{E} 2 \mathrm{~b})$ must represent the acetyltransferase (E2) component (Fig. 3).

Quantitative densitometry of the stained components of the purified complex (Fig. 3) suggested a molar ratio of E1:E2:E3 of $3: 1: 1$ but this was not corrected for differences in the staining affinities of the individual components.

Peptide mapping. Stained components from sodium dodecyl sulphate-polyacrylamide electrophoresis gels of the purified $P$. aeruginosa and $E$. coli complexes were examined by limited proteolysis with Staphylococcus aureus V8 protease and one-dimensional electrophoresis. The E1 components of both species resembled each other in 10 out of 15 visible digestion products. The E2a and E2b components of $P$. aeruginosa gave identical fragments and these were very different from the fragmentation pattern obtained from the E2 component of E. coli. The E3 components of the two species also responded differently.

Immunology. The $E$. coli pyruvate dehydrogenase complex produced two precipitin lines 


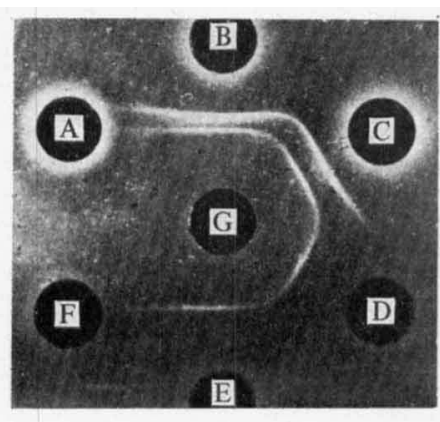

(a)

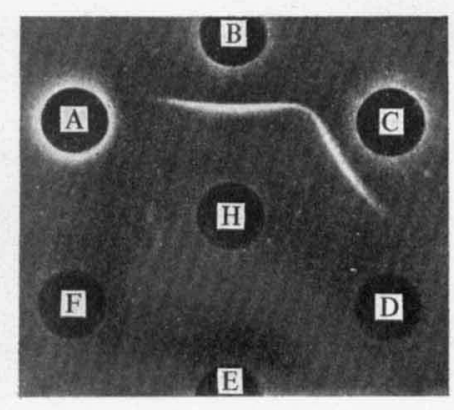

(b)

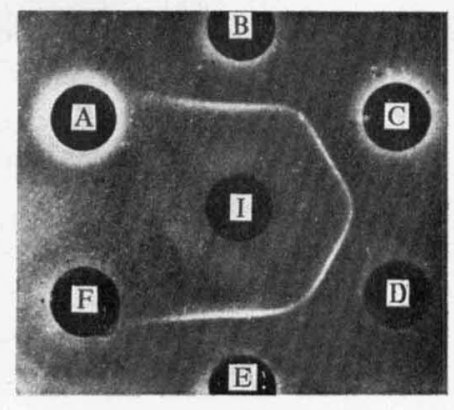

(c)

Fig. 4. Ouchterlony double diffusion in agarose. Centre wells (G, H and I) contained antiserum and lateral wells (A to $\mathrm{F}$ ) contained crude extract equivalent to $100 \mu \mathrm{g}$ protein: $\mathbf{A}, P$. aeruginosa PAO1 (wild type); B, E. coli (wild type); C to F, E. coli deletion strains described by Langley \& Guest (1977) [C, K $\Delta 27\left(\mathrm{E} 1^{+} \mathrm{E} 2^{+} \mathrm{E} 3^{+}\right)$; D, C $\Delta 42\left(\mathrm{E} 1^{-} \mathrm{E} 2^{+} \mathrm{E} 3^{+}\right) ; \mathrm{E}, \mathrm{H} \Delta 10\left(\mathrm{E} 1^{-} \mathrm{E} 2^{-} \mathrm{E} 3^{+}\right) ; \mathrm{F}, \mathrm{K} \Delta 18$ $\left.\left(\mathrm{E} 1^{-} \mathrm{E} 2^{-} \mathrm{E} 3^{-}\right)\right] ; \mathrm{G}$, anti-E. coli pyruvate dehydrogenase complex $(3 \mu \mathrm{l}) ; \mathrm{H}$, anti-E. coli pyruvate dehydrogenase component, E1 $(5 \mu \mathrm{l})$; I, anti-E. coli lipoamide dehydrogenase, E3 (3 $\mu \mathrm{l})$.

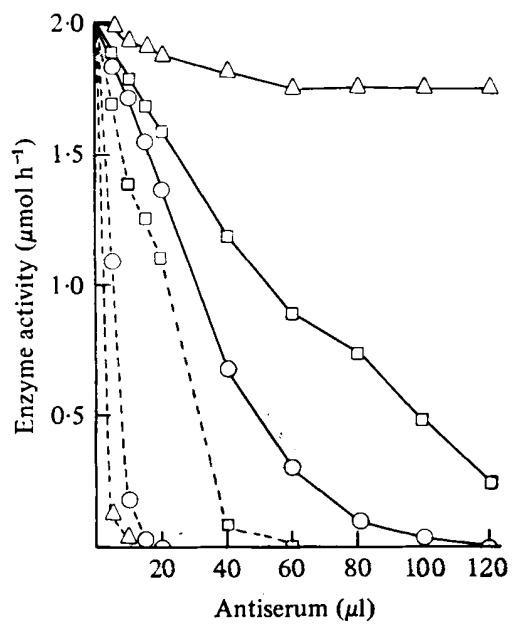

Fig. 5. Effect of antibodies raised against the $E$. coli pyruvate dehydrogenase complex (O), its pyruvate dehydrogenase component, E1 $(\square)$ and lipoamide dehydrogenase component, E3 $(\triangle)$ on the overall pyruvate dehydrogenase complex activity of $E$. coli $(---)$ and $P$. aeruginosa PAO1 $(-)$. Titrations of enzymic activities with antisera were carried out as described in Methods.

in double diffusion with the homologous antiserum (Fig. $4 a$ ). These were identified as specific reactions involving pyruvate dehydrogenase (outer line, Fig. $4 b$ ) and lipoamide dehydrogenase (inner line, Fig. $4 c$ ) by using the corresponding antisera and appropriate strains. Because the E1 and E3 components surround the acetyltransferase core, antisera raised against the complex may not contain anti-E2 antibodies or these antibodies may be unable to penetrate the complex and react with the core. No immunological cross-reaction was observed by Ouchterlony double diffusion between $P$. aeruginos $a$ and antisera raised against the $E$. coli pyruvate dehydrogenase complex or its E1 and E3 components. However, evidence for immunological cross-reactivity between the species was obtained in quantitative tests (Fig. 5). The overall pyruvate dehydrogenase complex activity of $P$. aeruginosa was precipitated by antibodies raised against the $E$. coli complex and its E1 component. The antiserum to the E3 component of $E$. coli was considerably less active, even after accounting for the proportion of $\mathrm{E} 3$ component that is associated with the 2-oxoglutarate dehydrogenase 
Table 2. Specific activities of the pyruvate dehydrogenase complex and components in P. aeruginosa PAO1 and ace mutants

Enzymes in ethanol-Sepharose 2B fractions derived from $10 \mathrm{~g}$ wet wt bacteria were assayed as described in Methods. Abbreviations as in Table 1; ND, not detected.

\begin{tabular}{|c|c|c|c|c|}
\hline \multirow[b]{2}{*}{ Strain } & \multicolumn{4}{|c|}{ Specific activity [units (mg protein) $)^{-1}$ ] } \\
\hline & pdhc & E1 & E2 & E3 \\
\hline PAOI $\left(a c e^{+}\right)$ & 0.61 & 0.23 & 0.29 & $0 \cdot 26$ \\
\hline PAO2851 (ace) & ND & $0 \cdot 10$ & 0.02 & 0.14 \\
\hline PAO2852 (ace) & ND & ND & 0.23 & $0 \cdot 19$ \\
\hline PAO2853 (ace) & ND & ND & 0.22 & $0 \cdot 18$ \\
\hline PAO2854 (ace) & ND & ND & 0.22 & $0 \cdot 18$ \\
\hline
\end{tabular}

complex in $P$. aeruginosa. Control serum had no effect on the enzyme activities. These results indicate that the pyruvate dehydrogenase components of $P$. aeruginosa and $E$. coli are related immunologically despite the negative precipitin reaction.

\section{Characterization of the pyruvate dehydrogenase complex mutants}

Previous attempts to define the lesions of ace mutants of $P$. aeruginosa by assaying for the individual components in crude cell-free extracts were inconclusive (Jeyaseelan \& Guest, 1980). Further attempts at characterizing the mutants were made by partial purification of the corresponding pyruvate dehydrogenase complexes by affinity chromatography on ethanol-Sepharose 2B. The mutant complexes were isolated in the fractions eluted immediately after the 2-oxoglutarate dehydrogenase complex in separations analogous to that shown in Fig. 1. The elution profiles for the mutants were similar to the wild type strain except that the second peak of lipoamide dehydrogenase activity was not associated with any pyruvate dehydrogenase complex activity. This not only served to identify the fractions containing the mutant complexes, but also demonstrated that inactive complexes are assembled by the mutants, because uncomplexed lipoamide dehydrogenase is eluted at a different position (J. Visser, unpublished observation). Assays for specific components (Table 2) indicated that the ace mutants lacked either the pyruvate dehydrogenase component (PAO2852 to 4) or the dihydrolipoamide acetyltransferase component (PAO2851), and the corresponding genes were designated ace $A$ (E1 component) and ace $B$ (E2 component), respectively. Electrophoretic analyses of the partially purified preparations on sodium dodecyl sulphate-polyacrylamide gels showed that polypeptides corresponding to the defective components were present in each mutant, indicating that they are probably missense mutants.

\section{DISCUSSION}

The pyruvate dehydrogenase complex of $P$. aeruginosa was intermediate in size between those of Escherichia coli and Azotobacter vinelandii but possessed a single-chain pyruvate dehydrogenase component, typical of Gram-negative bacteria. It contained three major and one minor polypeptide chains, identified as pyruvate dehydrogenase $\left(E 1 ; M_{r} 92500\right)$, acetyltransferase (E2a and E2b; $M_{r} 77800$ minor and 76000 major) and lipoamide dehydrogenase $\left(\mathrm{E} 3 ; \mathrm{M}_{\mathrm{r}} 58000\right)$. Compared with $E$. coli, the $\mathrm{E} 1$ and $\mathrm{E} 2$ components are smaller and the E3 component is larger. However, the relatively large difference in sedimentation coefficients ( 60 and $48 \mathrm{~S}$ ) is unlikely to stem from size differences of the components but rather from significant differences in the compositions of the complexes of the two species. Peptide mapping confirmed that the two polypeptides designated as acetyltransferase components probably have a common origin. Whether they are both invested with acetyltransferase activity was not investigated. In $E$. coli the sizes quoted for the acetyltransferase vary widely 
$\left(\mathrm{M}_{\mathrm{r}} 65000\right.$ to 89000$)$ and this component is exceedingly prone to spontaneous and proteolytic degradation into enzymically active products as small as 35000 (Angelides et al., 1979; Gebhardt et al., 1978; Hale \& Perham, 1979; Reed, 1974; Vogel, 1977; Vogel et al., 1971). It is probable that the frequently reported 80000 to 83000 component is really a degradation product of a larger, 89000 , native acetyltransferase (Gebhardt et al., 1978). The $P$. aeruginosa complex was prepared in the presence of a protease inhibitor and EDTA to limit proteolysis. Nevertheless, the $M_{r} 76000$ component could be derived from the 77800 component, but no smaller components were observed. The existence of two acetyltransferase components $\left(M_{r} 82000\right.$ and 59000) has been demonstrated for Azotobacter vinelandii (Bresters et al., $1975)$ and preliminary studies indicate that two polypeptides $\left(M_{r} 73000\right.$ and 65000$)$ are associated with the acetyltransferase of $P$. fluorescens (J. Visser, unpublished observations) but it is not certain whether the two proteins have a common origin.

Immunological cross-reactivity between the $E$. coli and $P$. aeruginosa complexes was weak but could be detected by quantitative tests, particularly for the E1 components. It may be significant that the respective $E 1$ components showed similar degradation patterns in peptide mapping. No similarities between the E2 and E3 components of the two species were detected other than the heat stability of lipoamide dehydrogenase.

Partial purification of the two complexes from mutants lacking pyruvate dehydrogenase complex activity permitted the identification of two classes of ace mutant. Three of the mutants, designated ace $A$, lacked pyruvate dehydrogenase activity (E1 component) and one mutant, designated $a c e B$, was deficient in acetyltransferase activity (E2 component). Polypeptides corresponding to the defective components were detected and this is consistent with the mutants possessing missense mutations and assembling enzymically inactive complexes. Previous genetic studies with the ace mutants have shown that their mutations are closely linked (Jeyaseelan \& Guest, 1980). Consequently, the results are consistent with the existence of an ace operon containing ace $A$ (E1) and ace $B$ (E2) genes similar to the ace operon of E. coli (Henning et al., 1966; Guest, 1978).

We wish to thank Professor B. W. Holloway for his generous gift of $P$. aeruginosa PAO1 and K.J. acknowledges the receipt of a postgraduate award from The Commonwealth Commission in the United Kingdom.

\section{REFERENCES}

Angelides, K. J., Akiyama, S. K. \& Hammes, G. G. (1979). Subunit stoichiometry and molecular weight of the pyruvate dehydrogenase multienzyme complex from Escherichia coli. Proceedings of the National Academy of Sciences of the United States of America 76, 3279-3283.

Bates, D. L., Danson, M. J., Hale, G., Hooper, E. A. \& Perham, R. N. (1977). Self-assembly and catalytic activity of the pyruvate dehydrogenase multienzyme complex of Escherichia coli. Nature, London 268, 313-316.

Bresters, T. W., De Abreu, R. A., De Kok, A., VISSER, J. \& VEeger, C. (1975). The pyruvate dehydrogenase complex from Azotobacter vinelandii. 1. Purification and properties. European Journal of Biochemistry 59, 335-345.

Cleveland, D. W. ., Fischer, S. G., Kirschner, M. W. \& Laemmli, U. K. (1977). Peptide mapping by limited proteolysis in sodium dodecyl sulphate and analysis by gel electrophoresis. Journal of Biological Chemistry 252, 1102-1106.

Danson, M. J., Hale, G., Johnson, P., Perham, R. N., Smith, J. \& SPRaGG, P. (1979). Molecular weight and symmetry of the pyruvate dehydro- genase multienzyme complex of Escherichia coli. Journal of Molecular Biology 129, 603-617.

De Abreu, R. A., De KoK, A. \& Veeger, C. (1977). Transformation of the 4-component pyruvate dehydrogenase complex from Azotobacter vinelandii into a 3-component complex. FEBS Letters 82, 89-92.

Fuller, C. C., Reed, L. J., Oliver, R. M. \& HACKerT, M. L. (1979). Crystallization of a dihydrolipoyl transacetylase-dihydrolipoyl dehydrogenase sub-complex and its implications regarding the subunit structure of the pyruvate dehydrogenase complex from Escherichia coli. Biochemical and Biophysical Research Communications $90,431-438$.

Gebhardt, T., Mecke, D. \& Bisswanger, H. (1978). Dihydrolipoamide transacetylase from Escherichia coli: evidence for internal gene duplication. Biochemical and Biophysical Research Communications 84, 508-514.

GUEST, J. R. (1978). Aspects of the molecular biology of lipoamide dehydrogenase. Advances in Neurology 21, 219-244.

Guest, J. R. \& Creaghan, I. T. (1974). Further 
studies with lipoamide dehydrogenase mutants of Escherichia coli K12. Journal of General Microbiology 81, 237-245.

HAGER, L. P. \& Kornberg, H. L. (1961). On the mechanism of $\alpha$-oxoglutarate oxidation in Escherichia coli. Biochemical Journal 78, 194-198.

Hale, G. \& Perham, R. N. (1979). Limited proteolysis of the pyruvate dehydrogenase complex of Escherichia coli. European Journal of Biochemistry 94, 119-126.

Henderson, C. E., Perham, R. N. \& Finch, J. T. (1979). Structure and symmetry of Bacillus stearothermophilus pyruvate dehydrogenase multienzyme complex and implications for eucaryote evolution. Cell 17, 85-93.

Henning, U., Dennert, G., Hertel, R. \& Shipp, W.S. (1966). Translation of the structural gene of the $E$. coli pyruvate dehydrogenase complex. Cold Spring Harbor Symposia on Quantitative Biology 31, 227-234.

JeYASEELAN, K. \& Guest, J. R. (1980). Isolation and properties of pyruvate dehydrogenase complex mutants of Pseudomonas aeruginosa PAO. Journal of General Microbiology 120, 385-392.

LAEMmLI, U. K. (1970). Cleavage of structural proteins during the assembly of the head of bacteriophage T4. Nature, London 227, 680-685.

LANGley, D. \& Guest, J. R. (1974). Biochemical and genetic characteristics of deletion and other mutant strains of Salmonella typhimurium LT2 lacking $\alpha$-keto acid dehydrogenase complex activities. Journal of General Microbiology 82, 319-335.
LANGley, D. \& Guest, J. R. (1977). Biochemical genetics of the $\alpha$-keto acid dehydrogenase complexes of Escherichia coli $\mathrm{K} 12$ : isolation and biochemical properties of deletion mutants. Journal of General Microbiology 99, 263-276.

REED, L. J. (1974). Multienzyme complexes. Accounts of Chemical Research 7, 40-46.

Stanisich, V. \& Holloway, B. W. (1972). A mutant sex factor of Pseudomonas aeruginosa. Genetical Research 19, 91-108.

STUdier, F. W. (1973). Analysis of bacteriophage T7 early RNAs and proteins on slab gels. Journal of Molecular Biology 79, 237-248.

Visser, J., VAN Dongen, W. \& Strating, M. (1978). Ethanolamine, a useful ligand for large scale purification of bacterial pyruvate dehydrogenase complex by affinity chromatography. FEBS Letters 85, 81-85.

VoGEL, O. (1977). Redetermination of the molecular weights of the components of the pyruvate dehydrogenase complex from $E$. coli K12. Biochemical and Biophysical Research Communications 74, 1235 1241.

Vogel, O., Beikirch, H., Muller, H. \& Henning, U. (1971). The subunit structure of the Escherichia coli K12 pyruvate dehydrogenase complex: the dihydrolipoamide transacetylase component. European Journal of Biochemistry 20, 169-178.

Vogel, O., Hoehn, B. \& Henning, U. (1972). Molecular structure of the pyruvate dehydrogenase complex from Escherichia coli K12. Proceedings of the National Academy of Sciences of the United States of America 69, 1615-1619. 